\title{
Construction of Non-Operational Asset Management Performance Index System in Chinese Colleges and Universities
}

\author{
Shu CHEN ${ }^{1,2, a}$, Xiao-Meng PAN ${ }^{2}$ \\ ${ }^{1}$ Finance Department of the Ministry of Education \\ ${ }^{2}$ Institutes of Technology of South China \\ a email:blueskychen@vip.163.com
}

Keywords: Performance index system, Asset management, Education.

\begin{abstract}
For the performance evaluation of the management of colleges and universities' non-operating assets, it is not mature either in the government's department or in colleges and universities. It is still in the exploratory stage and the difficulties encountered are also numerous. This paper analyzes the non-operating assets of colleges and universities from a macro management by using the method of literature analysis and questionnaire survey, and builds a performance evaluation index system for non-operating assets management. The purpose of this study is to analyze whether colleges and universities manage the assets according to laws, and ensure the operation is under the government macro management and supervision, as to ensure its security and compliance. The construction of non-operating asset management performance evaluation index system in colleges and universities can provide a quantitative and reliable asset management decision-making basis for the leaders of universities, which is conducive to the reform and innovation of asset management in colleges and universities.
\end{abstract}

\section{Introduction}

At present, the performance evaluation in higher education is mainly carried out in two aspects: scientific research performance and financial performance. But it is not mature either in the government's department or in colleges and universities for the performance evaluation of the management of colleges and universities' non-operating assets (which is not market operated). It is still in the exploratory stage and the difficulties encountered are also numerous. The reason is that colleges and universities are the main body of public products and services, and most of the assets that they occupy and use have obvious publicity. On the other hand, as a combination of two functions of educating and scientific research, colleges and universities do not aim at profit, and the output of their non-operational assets is difficult to quantify accurately. Therefore, it has led to the lack of impetus for colleges and university undertakings reform and innovation of asset management.

This paper analyzes the characters of non-operating assets of colleges and universities from a perspective of macro management by using the method of literature analysis and questionnaire survey, and builds a performance evaluation index system for non-operating assets management. It aimed at make sure whether colleges and universities manage the assets of colleges and universities according to laws, and ensure the operation is under the national macro management and supervision, as to ensure its security and compliance. This paper builds the index system according to the progress "input--process--output", which is corresponding to investment management, process management, efficiency and effectiveness management of assets.

The main contributions of this paper is: first, the research on assets management of colleges and universities is a hot topic in academic in recent years. However, in the existing relevant literature, little of the works is focused on the non-operating asset, most of them are focus on such as "fixed assets", "intangible assets of colleges and universities", "assets of university-run enterprise" and so on. This paper forms a clear and complete theoretical framework of perform appraisal of non-operating asset of college and university. Second, this paper builds a scientific and feasible performance evaluation index system for non-operating assets management in Colleges and 
universities, and provides a new perspective for the future research of performance evaluation index system of asset management in Colleges and universities. This can provide a quantitative and reliable asset management decision-making basis for the leaders of universities, which is conducive to the reform and innovation of asset management in colleges and universities. Through the construction of the performance evaluation index system of asset management in colleges and universities, the leaders can know the use of their own college assets, and recognize the existing problems of their own asset allocation, so that they can formulate their own goals for the development of universities, promote the reform and innovation to strengthen the performance responsibility of asset management in colleges and universities, and promote the sustainable development of colleges and universities.

The following parts of this paper is as follows: in sector II, it is a review of literature related to the performance of university asset management. Then, based on the literature review, it's the preliminary construction of the non-profit asset management performance index system of universities, and next is the verification of rationality of the index system by the method of questionnaire survey. The last part is the summary and the discussion of the next research.

\section{Related Literature Review}

We collate relevant articles from CNKI, and these papers can be divided into the following types from perspective of performance evaluation.

1. Some authors stand on a relatively broad angle to evaluate the index system. For example, Yue Yang (2015) hopes to make a reasonable assessment of utilization and income of educational resources, and provide a concrete and feasible reference for the optimal allocation of educational resources in colleges and universities, and finally achieve the operation of educational public products according to the benefit model. Jun Liu (2009) conducts performance evaluations from multiple perspectives of decision makers such as government, education authorities, and school administrative departments as well as college asset management clients such as universities' teachers and students. Xiang-rong Qiu (2002) stands on the perspective of information users of performance analysis in colleges and universities-government, investors and creditors to consider. Hong-li Chen (2010) carries out performance evaluation from the main body of the performance evaluation of university assets management, namely, the state, local governments, creditors and university administrators. Said its "widespread", is due to the large number of objects in asset management performance appraisal. If all the objects are considered, it will inevitably make people feel "want to catch everything".

2. Some authors evaluate college assets from a specific perspective. For example, Shan-qing Zhao(2015) appraise assets management about public universities. Yi-dan Yuan (2015) evaluates financial performance of state-owned assets from the perspective of finance. Yu-zhou Zhang (2009) inspects the performance of asset management in various departments from the perspective of university administrators, so as to achieve the Pareto optimal status of university asset use.

3. Other authors choose different evaluation methods for university assets evaluation. Such as Yan Zhang (2015) evaluates the assets of universities based on input-output analysis. Based on the concept of input-output model for evaluating the performance of university asset management, Hong-ling Chai (2010) use the grey correlation method to determine the content of indicators. Yan-li Jiang (2013) follows the logic of “input-process-output-effect” to evaluate. Jing Tan (2009) always focuses on the main line of "safeguard conditions - management ability - operational efficiency - actual effect” in the evaluation of high administrative state assets, and so on.

Different evaluation has different emphasis in the evaluation of assets of colleges and universities. This article evaluates the university's non-operating assets from the perspective of the government's macro management. The main purpose is to fully reflect the current status of the university's asset management and to ensure the security and compliance. Therefore, when analyzing and summarizing the related literature, this article prefers to draw lessons from the asset management evaluation that related to the above discussion. 


\section{The Preliminary Construction of Performance Evaluation Index System}

As there is no unified and authoritative index system for the performance appraisal of university business asset management, this paper mainly adopts the literature analysis method. First, we review the articles about the performance evaluation of university assets from the CNKI, and integrates the evaluation angle and the main evaluation index of these articles to determine whether the indicators of these articles have reference significance. After the selection of indicators, based on the relevant research results of the performance evaluation index system of asset management in colleges and universities which have reference significance, and combined with the guiding ideology, construction ideas and construction principles of the performance evaluation index system of university asset management to select the indicators one by one. The preliminary construction steps mainly include the following three steps:

Step 1: Compare the indicators and determine the index with reference significance. We review the literature on the performance evaluation of university asset management, and based on the basis of this article, from the perspective of the government's macro management to analyze the assets of major universities and colleges, so as to ensure the security, compliance and institutional nature of university assets, and determine whether the articles have reference significance.

Step 2: Grasp the overall situation and determine the indicators at all levels. On the basis of referential articles, combining the development history and characteristics of the university's assets, according to the construction logic of "input--process--output", the index will be set up from three first-level indicators: the asset security level (input), the asset management level (process), the asset operational level (output, efficiency and effect).

Step 3: Analyze the characteristics of the initially constructed index system structure. We analyze the ratios of conventional indicators and innovation indicators, quality indicators and quantitative indicators in the index system. At the same time, emphasis the significance of the selection of innovation indicators, and try to understand the initial set of indicators further clearly.

The details of the index system are as follows:

\section{Asset Security Level}

"Input" is mainly reflected in the level of asset security. The level of asset security is an objective reflection of the investment in the assets of the input of university business assets. In the construction of the level of asset security, this paper mainly refers to the research of Jing Tan (2009), Han-jie Lin (2014), Jun Deng (2012), Ying-jie Wu (2013), etc. on the management of university assets. The reference contents are shown in the following table:

Table 1. Sources of secondary indicators for asset security level

\begin{tabular}{|c|c|c|c|c|c|c|c|}
\hline Jing Tan & Sig. & Jun Deng & Sig. & Ying-jie $W u$ & Sig. & Han-jie Lin & Sig. \\
\hline Asset Scale & $\sqrt{ }$ & $\begin{array}{c}\text { The scale of } \\
\text { state-owned assets }\end{array}$ & $\sqrt{ }$ & $\begin{array}{l}\text { Asset scale } \\
\text { structure }\end{array}$ & $\sqrt{ }$ & Asset Scale & $\sqrt{ }$ \\
\hline $\begin{array}{c}\text { Assets } \\
\text { Structure }\end{array}$ & $\sqrt{ }$ & State assets structure & $\sqrt{ }$ & Asset allocation & $\sqrt{ }$ & $\begin{array}{c}\text { Assets } \\
\text { Structure }\end{array}$ & $\sqrt{ }$ \\
\hline $\begin{array}{l}\text { Asset } \\
\text { Quality }\end{array}$ & $\sqrt{ }$ & $\begin{array}{l}\text { The situation of } \\
\text { state-owned assets } \\
\text { preservation }\end{array}$ & $\sqrt{ }$ & Talent cultivation & $x$ & $\begin{array}{l}\text { Asset } \\
\text { Quality }\end{array}$ & $\sqrt{ }$ \\
\hline \multirow[t]{2}{*}{$\begin{array}{l}\text { Occupancy } \\
\text { Level }\end{array}$} & $\sqrt{ }$ & $\begin{array}{c}\text { The situation of } \\
\text { state-owned assets } \\
\text { utilization }\end{array}$ & $x$ & & & & \\
\hline & & $\begin{array}{c}\text { Teaching and } \\
\text { scientific research } \\
\text { achievements }\end{array}$ & $x$ & & & & \\
\hline
\end{tabular}

On the basis of the author's construction of the index of the level of asset security in colleges and universities, in accordance with the thinking of fully reflecting the investment of university assets, there are four two level indexes under the level of asset security: asset scale, asset structure, asset 
quality and student average level. These four secondary indicators can fully reflect the information of different colleges and universities' stock assets and reflect the current status of the allocation of business assets in different universities. By understanding the status of investment in the assets of institutions of higher learning in different universities, it is possible to compare and analyze the degree of support and guarantee for the development of talent training, scientific research, social services, and cultural inheritance in different colleges and universities, and to evaluate the fairness of asset allocation in institutions of higher learning.

\section{Asset Management Level}

Asset management level is the main embodiment of the "process" in evaluation logic. This index is an important index reflecting the operational environment of university assets. The construction of asset management level index mainly refers to the study of Jing Tan (2012), Yan Zhang (2015), Han-jie Lin (2014) and Xiao-jun Deng (2012).

Table 2. Reference Sources of Secondary Level Indicators for Asset Management Level

\begin{tabular}{|c|c|c|c|c|c|c|c|}
\hline Jing Tan & Sig. & Yan Zhang & Sig. & Han-jie Lin & Sig. & Xiaojun Deng & Sig. \\
\hline Organization & $\sqrt{ }$ & $\begin{array}{c}\text { Management } \\
\text { system }\end{array}$ & $\sqrt{ }$ & $\begin{array}{c}\text { Management Team } \\
\text { Construction }\end{array}$ & $\sqrt{ }$ & $\begin{array}{c}\text { Management } \\
\text { team evaluation }\end{array}$ & $\sqrt{ }$ \\
\hline $\begin{array}{c}\text { Institutional } \\
\text { construction }\end{array}$ & $\sqrt{ }$ & $\begin{array}{c}\text { Institutional } \\
\text { setting and } \\
\text { staffing }\end{array}$ & $\sqrt{ }$ & $\begin{array}{c}\text { Management } \\
\text { mechanism } \\
\text { construction }\end{array}$ & $\sqrt{ }$ & $\begin{array}{c}\text { Management } \\
\text { mechanism } \\
\text { evaluation }\end{array}$ & $\sqrt{ }$ \\
\hline The degree of \\
informatization
\end{tabular}

Based on the above-mentioned indicators, with the idea of fully embodying the process control of the assets of institutions of higher learning, there are four secondary indicators at the level of asset management: organizational structure, system construction, staffing and information level. These four secondary indicators can fully reflect the organizational construction, system construction, personnel structure and asset management information status of different colleges and universities, and reflect the management ability of different university asset management institutions, which will help the government to fully understand the status of asset management in various colleges and universities.

\section{Asset Operational Level}

"Efficiency and effect" is the embodiment of the operation level of the assets. The operation level of the assets is the core of the performance evaluation index system of the whole university's enterprise assets, and it is the index which can reflect the use and possession of the efficiency of university's business assets. For the construction of this part of the index system, this paper mainly 
refer to the research of Jing Tan (2009), Ying-jie Wu (2013), Ya-li Ji (2008), Jin-zhu Zhao (2008) and others.

Table 3. Reference Sources of Secondary Level Index for Asset Operation Level

\begin{tabular}{|c|c|c|c|c|c|c|c|}
\hline Jing Tan & Sig. & Ying-jie Wu & Sig. & Ya-li Ji & Sig. & Jin-zhu Zhao & Sig. \\
\hline $\begin{array}{c}\text { Property } \\
\text { management }\end{array}$ & $\sqrt{ }$ & Capital budget & $x$ & $\begin{array}{l}\text { Asset scale } \\
\text { evaluation }\end{array}$ & $\sqrt{ }$ & $\begin{array}{l}\text { Asset budget } \\
\text { source }\end{array}$ & $x$ \\
\hline $\begin{array}{l}\text { Asset use } \\
\text { efficiency }\end{array}$ & $\sqrt{ }$ & $\begin{array}{c}\text { Capital } \\
\text { investment and } \\
\text { use }\end{array}$ & $\sqrt{ }$ & $\begin{array}{c}\text { Asset } \\
\text { structure }\end{array}$ & $\sqrt{ }$ & $\begin{array}{l}\text { Investment and use } \\
\text { of assets }\end{array}$ & $\sqrt{ }$ \\
\hline $\begin{array}{c}\text { Asset disposal } \\
\text { efficiency }\end{array}$ & $\sqrt{ }$ & $\begin{array}{l}\text { The efficiency of } \\
\text { funds }\end{array}$ & $\sqrt{ }$ & $\begin{array}{c}\text { Asset } \\
\text { utilization }\end{array}$ & $\sqrt{ }$ & $\begin{array}{l}\text { Asset usage } \\
\text { efficiency }\end{array}$ & $\sqrt{ }$ \\
\hline $\begin{array}{c}\text { Asset income } \\
\text { management }\end{array}$ & $\sqrt{ }$ & $\begin{array}{l}\text { Research } \\
\text { situation }\end{array}$ & $x$ & $\begin{array}{c}\text { Team } \\
\text { evaluation }\end{array}$ & $\sqrt{ }$ & Available asset rate & $\sqrt{ }$ \\
\hline $\begin{array}{c}\text { Financial } \\
\text { Management }\end{array}$ & $x$ & $\begin{array}{l}\text { Academic } \\
\text { influence }\end{array}$ & $x$ & & & $\begin{array}{l}\text { Fixed assets update } \\
\text { rate }\end{array}$ & $\sqrt{ }$ \\
\hline Asset security & $\sqrt{ }$ & & & & & $\begin{array}{c}\text { Business fixed } \\
\text { assets usage rate }\end{array}$ & $\sqrt{ }$ \\
\hline $\begin{array}{l}\text { Daily operation } \\
\text { effect of the unit }\end{array}$ & $x$ & & & & & $\begin{array}{l}\text { Fixed asset sharing } \\
\text { rate }\end{array}$ & $\sqrt{ }$ \\
\hline $\begin{array}{l}\text { Performance of } \\
\text { unit public } \\
\text { functions }\end{array}$ & $x$ & & & & & Total asset turnover & $x$ \\
\hline Social satisfaction & $x$ & & & & & Asset-liability ratio & $\sqrt{ }$ \\
\hline & & & & & & $\begin{array}{l}\text { Cash flow debt } \\
\text { ratio }\end{array}$ & $x$ \\
\hline
\end{tabular}

Ensuring the safety and integrity of the assets of institutions of higher learning is the primary goal and prerequisite for asset management in colleges and universities. Most authors emphasize the output of university assets when they evaluate the assets of colleges and universities. Their evaluation targets are mostly "output" indicators. However, there are few references to the indicators of the efficiency and effectiveness of non-operating assets in colleges and universities. Therefore, in the construction of this index system, quantitative statistics and analysis are conducted mainly from five aspects: property rights management, asset utilization efficiency, asset disposal efficiency, asset income management, and asset security.

\section{Validation of Indicators' Rationality According to Questionnaire Survey Questionnaire Design and Data Collection}

In order to construct an evaluation index system from the perspective of scientific management better and fully reflects the comprehension of the assets managers of colleges and universities in the management of university business assets, this study decided to issue questionnaires to 750 business asset managers in 75 directly-affiliated universities to try to reflect the views and opinions of university asset managers on university performance evaluation. Therefore, this study selected 75 directly-affiliated universities of different regions and different types (Tsinghua University, Peking University, etc.) as the subjects of survey and distributed 10 questionnaires for each university in 75 colleges and universities (inquiry targets: school leaders, middle-level workers, and college business asset management workers). The questionnaire continues to adopt Likert's five-point rating scale method which allows the respondents to choose the importance of the indicators in the existing index system (namely "very important”, “more important”, "general importance”, "unimportant" and "removed"), and assigns 5 points, 4 points, 3 points, 2 points, and 1 points respectively. Up to now, 675 questionnaires have been collected from 73 colleges and universities, with an effective recovery rate of $86.81 \%$. The recovered questionnaires can be used for index 
selection on the one hand, and on the other hand, it is also an important basis for determining the weights of indicators. The details of the recovered questionnaires are as follows.

Table 4. The questionnaire recovery situation

\begin{tabular}{|c|c|c|c|c|c|c|}
\hline & \multirow{2}{*}{ Total } & \multicolumn{4}{|c|}{ Effective questionnaire } & \multirow{2}{*}{\begin{tabular}{c} 
Ineffective \\
\cline { 3 - 6 }
\end{tabular}} \\
\cline { 3 - 6 } & Subtotal & $\begin{array}{c}\text { School } \\
\text { leadership }\end{array}$ & $\begin{array}{c}\text { Middle-level } \\
\text { cadres }\end{array}$ & Staff & questionnaire \\
\hline Quantity & 675 & 586 & 138 & 202 & 246 & 89 \\
\hline Proportion & $100.00 \%$ & $86.81 \%$ & $23.55 \%$ & $34.47 \%$ & $41.96 \%$ & $13.19 \%$ \\
\hline
\end{tabular}

\section{Questionnaire Reliability Analysis}

Reliability refers to the degree of reliability, and evaluation reliability refers to the reliability of the assessment results. The internal consensus coefficient (Cronbach's Alpha) is widely used in academic circles to test the internal consistency reliability of the scale. Hair, Anderson, Taehan, et al. (1988) pointed out that the internal consistency coefficient greater than 0.7 indicates that the reliability of the scale is higher; In exploratory studies, the internal consistency coefficient may be less than 0.7, but should be greater than 0.6; Peter (2002) pointed out that when the number of questions is less than 6 and the internal consistency coefficient is greater than 0.6, indicating that the scale is valid.

In order to ensure the reliability of the questionnaire, the paper used SPSS 21.0 analysis software to analyze the reliability of the 675 valid questionnaires. In general, the overall Cronbach's Alpha of the questionnaire is 0.929, and the number of Cronbach's Alpha items based on the standardized item is 0.927 , indicating the high reliability of the questionnaire. At the same time, through the analysis of the reliability of each dimension, it was found that the asset protection level contains 21 evaluation indicators with a reliability coefficient of 0.903 ; the asset management level contains 13 evaluation indicators with a reliability coefficient of 0.789 ; the operation level of assets contains 21 evaluation indexes, and the reliability coefficient is 0.896 . The results show that the three dimensions satisfy the reliability test requirements, and the reliability is very good. The questionnaire is stable and reliable.

Table 5. Statistical analysis of reliability of questionnaire survey

\begin{tabular}{|c|c|c|c|}
\hline Project & $\begin{array}{c}\text { Cronbach's } \\
\text { Alpha }\end{array}$ & $\begin{array}{c}\text { Cronbach’s Alpha based on } \\
\text { standardized items }\end{array}$ & $\begin{array}{c}\text { Number of } \\
\text { items }\end{array}$ \\
\hline Total questionnaire & 0.929 & 0.927 & 13 \\
\hline Asset security level & 0.903 & 0.904 & 4 \\
\hline Asset management level & 0.789 & 0.806 & 4 \\
\hline Asset operating level & 0.896 & 0.897 & 5 \\
\hline
\end{tabular}

\section{Analysis of the Questionnaire's Validity}

Validity means effectiveness, which means that measuring tools or means can accurately measure the degree of things that need to be measured. The methods commonly used in the validity analysis of the questionnaire include content validity, construct validity and guideline validity. This paper mainly analyzes the content validity and construct validity of the index system.

(1) Content validity

Content validity refers to the extent to which the content covered by the measurement can represent all measured content. The wider range of coverage, the higher the content validity. When evaluating content validity, a combination of logical analysis and statistical analysis is usually used. Logical analysis refers to whether the content to be evaluated by a researcher or expert judgement "seems" to meet the purpose and requirements of the evaluation; Statistical analysis is based on the correlation coefficient between the single item and the sum to determine whether it is valid. The 
larger the correlation coefficient is, the higher the content validity of the questionnaire is. In this study, since the indicator system is constructed by three first-level indicators, calculating the scores of each item and the total score of the questionnaire is not of great significance. Therefore, the content validity analysis mainly focuses on the scales formed by the three first-level indicators, and does not analyze the content validity of the whole index system.

Table 6. Validity Analysis of Questionnaire Content

\begin{tabular}{|c|c|c|}
\hline \multicolumn{3}{|l|}{ “Asset security level” } \\
\hline \multirow{2}{*}{ Asset scale A1 } & Correlation coefficient & $0.668 * *$ \\
\hline & sig.(2-tailed) & 0.000 \\
\hline \multirow{2}{*}{ Asset structure A2 } & Correlation coefficient & $0.656 * *$ \\
\hline & sig.(2-tailed) & 0.000 \\
\hline \multirow{2}{*}{ Asset quality A3 } & Correlation coefficient & $0.528 * *$ \\
\hline & sig.(2-tailed) & 0.000 \\
\hline \multirow{2}{*}{ Average student level A4 } & Correlation coefficient & $0.502 * *$ \\
\hline & sig.(2-tailed) & 0.000 \\
\hline \multicolumn{3}{|l|}{ “Asset management level” } \\
\hline \multirow{2}{*}{ Organization B1 } & Correlation coefficient & $0.434 * *$ \\
\hline & sig.(2-tailed) & 0.000 \\
\hline \multirow{2}{*}{ Institutional construction B2 } & Correlation coefficient & $0.565 * *$ \\
\hline & sig.(2-tailed) & 0.000 \\
\hline \multirow{2}{*}{ Staffing B3 } & Correlation coefficient & $0.559 * *$ \\
\hline & sig.(2-tailed) & 0.000 \\
\hline \multirow{2}{*}{ Informationization degree B4 } & Correlation coefficient & $0.595 * *$ \\
\hline & sig.(2-tailed) & 0.000 \\
\hline \multicolumn{3}{|l|}{ “Asset operating level” } \\
\hline \multirow{2}{*}{ Property management C1 } & Correlation coefficient & $0.482 * *$ \\
\hline & sig.(2-tailed) & 0.000 \\
\hline \multirow{2}{*}{ Property usage efficie C2 } & Correlation coefficient & $0.431^{* *}$ \\
\hline & sig.(2-tailed) & 0.000 \\
\hline \multirow{2}{*}{ Asset disposal efficiency C3 } & Correlation coefficient & $0.513 * *$ \\
\hline & sig.(2-tailed) & 0.000 \\
\hline \multirow{2}{*}{ Asset income management C4 } & Correlation coefficient & $0.510 * *$ \\
\hline & sig.(2-tailed) & 0.000 \\
\hline \multirow{2}{*}{ Asset safety management C4 } & Correlation coefficient & $0.550 * *$ \\
\hline & sig.(2-tailed) & 0.000 \\
\hline
\end{tabular}

(2) Structural validity analysis

Structural validity refers to the degree of correspondence between certain structures and measured values that are reflected in the measurement results. The most ideal method for construct validity analysis is to use factor analysis for the structural validity of the measurement scale or the entire questionnaire. This paper carries out factor analysis on each level of the index system under the indicator system. Asset security level KMO results (0.824), asset management level KMO results (0.665), Bartlett spherical test results (chi $2=1753.090$, sig. $=0.000$ ), KMO result of asset security (0.839), Bartlett spherical test results (chi square) Sig. value $=0.000$ ), and the three first-level indexes sig. values are all less than 0.01 , indicating that the index system is suitable for factor analysis and has higher construct validity. 
Table 7. Descriptive statistical results of the questionnaire

\begin{tabular}{|l|l|l|l|}
\hline Index system(item) & mean & standard deviation & Coef. of variation \\
\hline Asset scale A1 & 3.87 & 0.817 & 0.21096 \\
\hline Asset structure A2 & 4.01 & 0.774 & 0.19290 \\
\hline Asset quality A3 & 4.43 & 0.581 & 0.13101 \\
\hline Average student level A4 & 4.16 & 0.716 & 0.17198 \\
\hline Organization B1 & 4.87 & 0.389 & 0.07993 \\
\hline Institutional construction B2 & 4.89 & 0.310 & 0.06328 \\
\hline Staffing B3 & 4.51 & 0.575 & 0.12741 \\
\hline Informationization degree B4 & 4.61 & 0.555 & 0.12042 \\
\hline Property management C1 & 4.32 & 0.769 & 0.17806 \\
\hline Asset usage efficiency C2 & 4.69 & 0.544 & 0.11611 \\
\hline Asset disposal efficiency C3 & 3.97 & 0.770 & 0.19378 \\
\hline Asset income management C4 & 4.49 & 0.594 & 0.13221 \\
\hline Asset safety management C5 & 4.67 & 0.564 & 0.12223 \\
\hline
\end{tabular}

According to the results of the questionnaire survey, in the construction of the secondary indicators under the first-level indicators, the arithmetic mean and coefficient of variation of the 13 secondary indicators meet the requirements; in the comment modification column of the questionnaire, there are no expert opinions on the elimination or modification of the secondary indicators. Therefore, the statistical results show that the survey respondents have basically the same opinions on the importance of the primary and secondary indicators.

\section{Conclusions and Discussion of Future Work}

By referring to the relevant literature, according to the guiding ideology, theoretical foundation, design principles and construction methods of the index system, this paper constructs a preliminary index system of the performance evaluation of non-operating assets management in Chinese colleges and universities. Through the initial indicator screening and large-scale release of indicator system survey questionnaires (750 questionnaires from 75 colleges and universities, the survey subjects including school leaders, middle-level workers, college business asset management workers, etc.), data analysis verified that the secondary indicators are reasonable. The index system embodies the scientific and feasibility of the whole process of asset management, and provides a new perspective for the future research on the performance evaluation index system of asset management in colleges and universities.

The future work includes: After determining the above-mentioned second-level indicators, this study would continue to build third-level indicators for the constructed indicator system. The third-level indicators seek to fully and comprehensively reflect the connotation of the corresponding secondary indicators. At the same time, they must also follow the principles for the construction of single index data, namely the principles of objectivity, relevance, availability, representativeness, etc. The majority of single indicator evaluation data should be obtained from the basic status tables of state-owned assets reports or the basic situation or statistical data of universities, which is conducive to the availability and objectivity of performance evaluation.

\section{Reference}

[1] Xiang-rong Qiu. Study on Asset Management and Performance Evaluation of Higher Education Institutions in China [D]. Kunming University of Science and Technology, 2003.

[2] Jin-zhu Zhao. The Research on Performance Evaluation of Non-operation Assets [D]. Changsha University of Science and Technology, 2008. 
[3] Yu-zhou Zhang, Xueying Zhang, Qing Cheng. Study on the Index System of Performance Appraisal on Capital Management of Colleges and Universities [J]. Journal of Tianjin Institute of Engineering Teachers, 2008, v.18; No.5704:48-51.

[4] Jun Liu. Performance Evaluation of Colleges and Universities' Asset Management and Empirical study [D].Xiangtan University, 2009.

[5] Ya-li Ji. Study on the Pattern of State-owned Asset Management and Performance Evaluation at Colleges and Universities [D]. Henan Polytechnic University, 2009.

[6] Hong-li Chen. Research on Performance Evaluation of Asset Management in Our Country's College [D]. Shandong University of Science and Technology, 2010.

[7] Hong-ling Chai. Research on Performance Evaluation of University Asset Management [D]. Hubei University,2010.DOI:10.7666/d.y1736971.

[8] Jing Tan. Study on the Performance Evaluation of Administrative State-owned Assets Management [D]. Research Institute for Fiscal Science, 2012.

[9] Xiao-jun Deng. Construction of Comprehensive Performance Evaluation Index System of Non-operating State-owned Assets in Colleges and Universities [J]. Communication of Finance and Accounting, 2012, 08:79-80.

[10] Yan-li Jiang. Study on The Index System of Performance Appraisal on Assets Used of Colleges and Universities [D]. Shandong University of Finance and Economics, 2013.

[11] Ying-jie Wu. Construction of the Guangdong Universities' State-owned Assets Management Performance Evaluation System [D].South China University of Technology, 2013.

[12] Han-jie Lin. Construction of Performance Evaluation Index System of State-owned Assets Management in Colleges and Universities [J]. Friends of Accounting, 2014, 16:115-118.

[13] Xi-shi Huang, Shanqing Zhao. Construction on Performance Evaluation Index System of State Asset Management in Colleges and Universities [J]. Experimental Technology and Management, 2014, 31(08):266-268

[14] Yan Zhang. Research on State-owned Assets Management Mode of Chinese Colleges and Universities from the Perspective of New Public Management [D]. Nanjing University of Aeronautics and Astronautics, 2015.

[15] Yi-dan Yuan. Construction and Application on Financial Performance Evaluation Index System of State-owned Assets in Shaanxi Provincial Universities [D]. Xi'an Polytechnic University, 2015.

[16] Yue Yang. Discussion on Performance Evaluation Index System of College Asset Management [J]. Manager, 2015, 26:231.

[17] Shan-qing Zhao. Research on the Construction of Evaluation Index System of Public University's Assets Use Performance [J]. Education Accounting Research, 2015, v.26; No.14906:31-36. 